\title{
Further taxonomic notes on the jumping spider Synemosyna maddisoni Cutler, 1985 (Araneae: Salticidae)
}

\author{
Аальнейшие таксономические сведения о пауке-скакунчике \\ Synemosyna maddisoni Cutler, 1985 (Araneae: Salticidae)
}

\section{David Chamé-Vázquez, ${ }^{1,}$, Bruce Cutler', Guillermo Ibarra-Núñez ${ }^{1}$ Аавид Хаме-Васкес ${ }^{1,}$, Брюс Катмер ${ }^{2}$, Гиермо Ибарра-Нуньес ${ }^{1}$}

\author{
${ }^{1}$ Colección de Arácnidos del Sureste de México, El Colegio de la Frontera Sur (ECOSUR), Tapachula, Chiapas, 30700, México. E-mail: \\ (DCV) chamevazquez@gmail.com; (GIN) gibarra@ecosur.mx \\ ${ }^{2}$ Department of Ecology and Evolutionary Biology, University of Kansas, 1200 Sunnyside Avenue, Lawrence, Kansas 66045-7534 USA. \\ E-mail: dbronx@ku.edu \\ "Corresponding author
}

KEY WORDS: Aranei, Mexico, diagnosis, pars pendula, redescription.

КЛЮЧЕВЫЕ СЛОВА: Aranei, Мексика, диагноз, pars pendula, переописание.

ABSTRACT: We examined a set of salticids from southern Mexico, all of them subsequently assigned to Synemosyna maddisoni Cutler, 1985, which has not been illustrated since the original description. Therefore, we have provided detailed micrographs of the copulatory organs of both sexes and remarks on the male palpus, which has a simple embolus with pars pendula and an apical sclerite. Moreover, we have emended the diagnosis taking in account the resemblance with S. ubicki Cutler, 1988 which was described after the original description of $S$. maddisoni.

How to cite this article: Chamé-Vázquez D., Cutler B., Ibarra-Núñez G. 2020. Further taxonomic notes on the jumping spider Synemosyna maddisoni Cutler, 1985 (Araneae: Salticidae) // Arthropoda Selecta. Vol.29. No.4. P.475-480. doi: 10.15298/arthsel. 29.4.10

РЕЗЮМЕ: Мы исследовали подборку сальтицид из южной Мексики и отнесли их к Synemosyna maddisoni Cutler, 1985, который никогда не иллюстрировался после первоописания. Поэтому мы публикуем детальные микрофотографии копулятивных органов обоих полов и даем заметки о пальпусе самца, в котором имеется простой эмболюс с pars pendula и апикальный склерит. Более того, мы также уточнили диагноз вида с учетом его сходства с S. ubicki Cutler, 1988, видом, который был описан после описания S. maddisoni.

\section{Introduction}

Synemosyna Hentz, 1846 is an American spider genus with 17 species distributed from the United States to Argentina [Galiano, 1966; Richman et al., 2012; WSC, 2020]. They and the closely related Sympolymnia Perger et Rubio, 2020 usually resemble Pseudomyrmex or Crematogaster ants [Cutler, 1985, 1988;
Galiano, 1966; Maddison, 2015; Perger, Rubio, 2020]. This resemblance by Synemosyna species is seen in morphological modifications such as elongate bodies, usually constricted carapace and abdomen, and slender legs. Some species are polymorphic and therefore resemble more than one ant model and some even mimic the ant locomotory behaviour [Cutler, 1985; Galiano, 1966; Oliveira, 1988; Reiskind, 1977]. Three species of Synemosyna: S. americana (Peckham et Peckham, 1885), S. decipiens (O. Pickard-Cambridge, 1896) and $S$. maddisoni Cutler, 1985; and one from the recently described genus Sympolymnia, S. edwardsi (Cutler, 1985) are known from Mexico (Fig. 24). Most Synemosyna species are rare in collections because in the field they are easily overlooked due to their myrmecomorphy. Here, we provide novel morphological information of the copulatory organs of both sexes of $S$. maddisoni, and update its diagnosis.

\section{Material and methods}

Specimens were measured by means of an ocular micrometer of an Olympus SZX16 stereomicroscope. The epigyne was cleared with methyl salicylate. Photographs were taken with a Nikon 5200 camera attached to a Zeiss Primo Star microscope; Helicon Focus software was used for image stacking. Scanning electron micrographs were taken with a TOPCON SM-510 at El Colegio de la Frontera Sur, Tapachula, following the procedures and methods described in Alvarez-Padilla \& Hormiga [2008]. Colour descriptions are based on the specimens preserved in $96 \%$ ethanol. All the specimens studied are deposited in the Colección de Arácnidos del Sureste de México, Tapachula, Chiapas, Mexico (ECOTAAR; curator: G. Ibarra-Núñez). The format of description follows Galiano [1963, 1966], except for legs of which measurements are presented as follows: total length (femur, patella, tibia, metatarsus, tarsus); all measurements are in millimeters. General terminology follows Ramirez [2014], spine notation follows Petrunkevitch [1925]. Ab- 

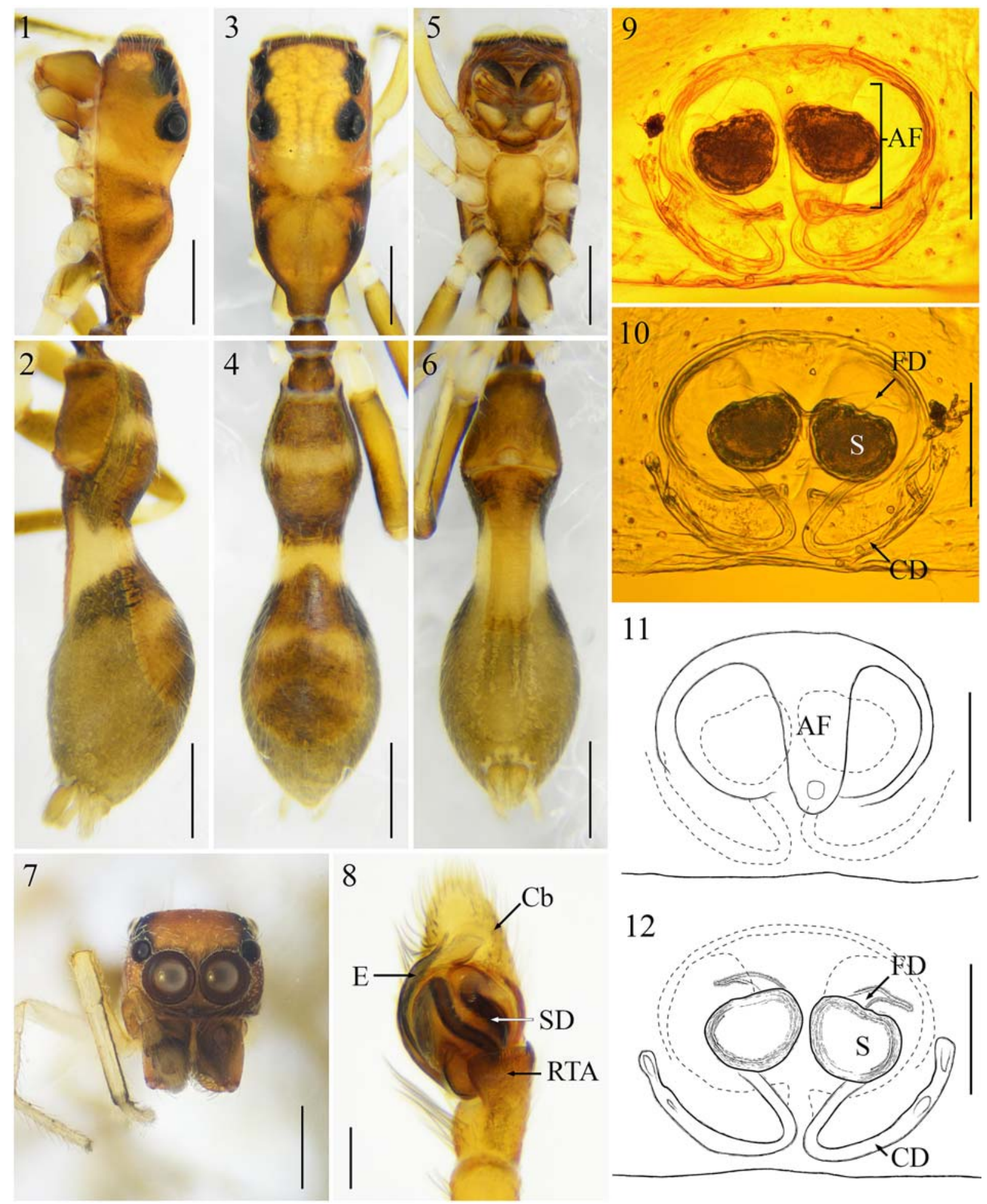

Figs 1-12. Synemosyna maddisoni Cutler, 1985: 1, 2 - male habitus, lateral view; 3, 4 - ditto, dorsal view; 5, 6 - ditto, ventral view; 7 - ditto, frontal view; 8 - left male palp, ventral view; 9,11 - epigyne, ventral view, 10, 12 - vulva, dorsal view. Scale bars: 0.5 $\mathrm{mm}(1-7), 0.1 \mathrm{~mm}(8-12)$. Abbreviations as explained in 'Material and Methods'.

Рис. 1-12. Synemosyna maddisoni Cutler, 1985: 1, 2 - габитус самца, вид сбоку; 3, 4 - то же, вид сверху; 5, 6 - то же, вид снизу; 7 - то же, вид спереди; 8 - левая пальпа самца, вид снизу; 9, 11 - эпигина, вид снизу, 10, 12 - вульва, вид сверху. Масштаб: 0,5 мм (1-7), 0,1 мм (8-12). Сокращения как объяснено в 'Материалах и Методах'. 

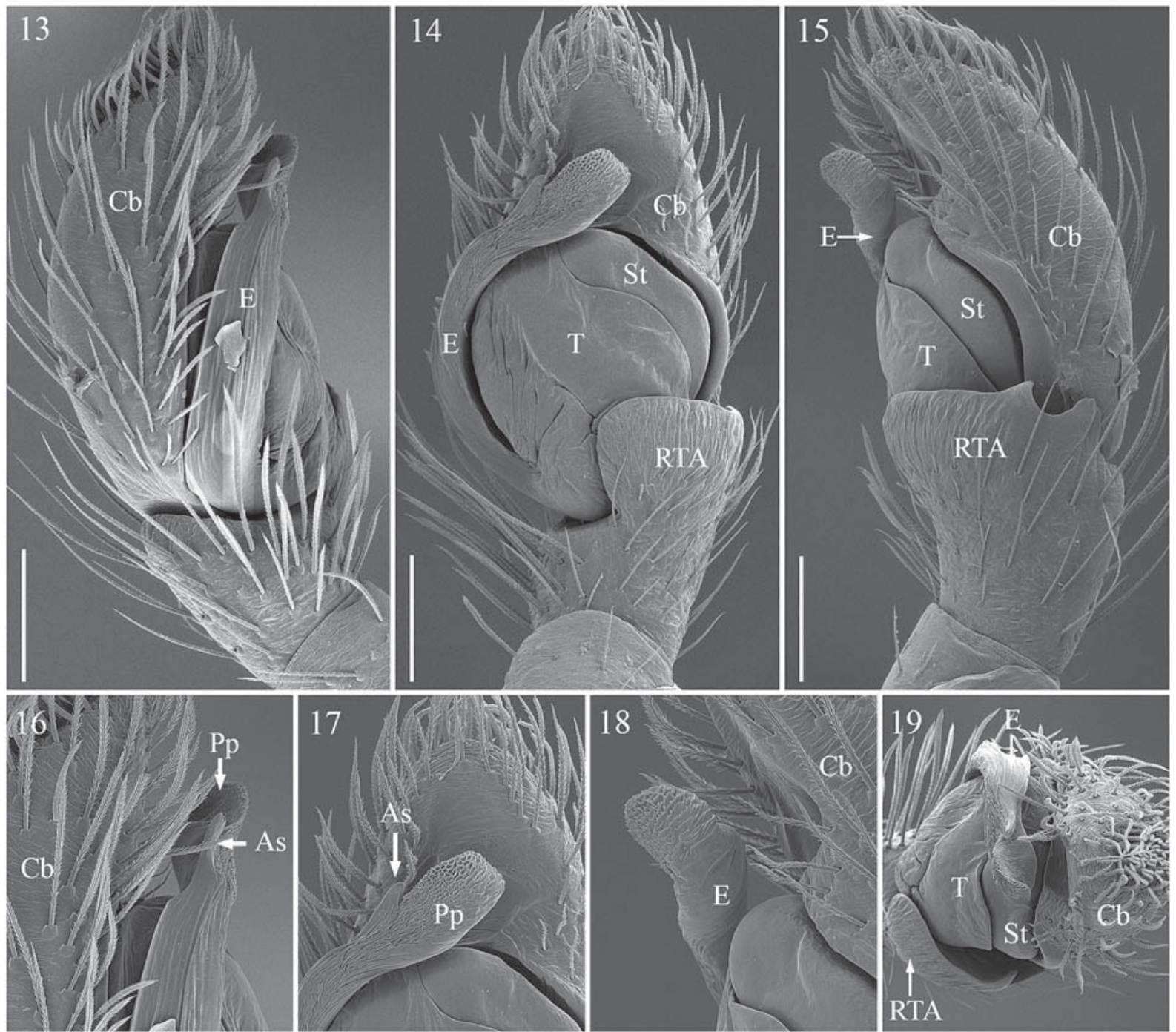

Figs 13-19. Synemosyna maddisoni Cutler, 1985: 13 - left male palp, prolateral view; 14 - ditto, ventral view; 15 - ditto, retrolateral view; 16 - apical division, prolateral view; 17 - ditto, ventral view; 18 - ditto, retrolateral view; 19 - ditto, apical view. Scale bars: $0.1 \mathrm{~mm}$. Abbreviations as explained in 'Material and Methods'.

Рис. 13-19. Synemosyna maddisoni Cutler, 1985: 13 - левая пальпа самца, вид спереди-сбоку; 14 - тоже, вид снизу; 15 тоже, вид сзади-сбоку; 16 - апикальный раздел, вид спереди-сбоку; 17 - тоже, вид снизу; 18 - тоже, вид сзади-сбоку; 19 тоже, вид спереди. Масштаб: 0,1 мм. Сокращения как объяснено в 'Материалах и Методах'.

breviations used in the text and figures are as follows: $\mathrm{AF}-$ anterior flap, As - apical sclerite of the embolus (sensu Comstock [1910]), $\mathrm{Cb}$ - cymbium, CD - copulatory duct, $\mathrm{D}$ - described, E - embolus, FD - fertilization duct, Pp pars pendula, RTA - retrolateral tibial apophysis, S spermatheca, SD - sperm duct, St — subtegulum, T tegulum.

\section{Taxonomy}

Salticidae Blackwall, 1841

Synemosyna Hentz, 1846

Synemosyna maddisoni Cutler, 1985 Figs 1-19

Synemosyna maddisoni Cutler, 1985: 89, figs 19-22 (Do + ). Holotype + from MEXICO, Chiapas, c. $10 \mathrm{~km} \mathrm{SW}$ of Ococingo on the road to Oxchuc, $16^{\circ} 09^{\prime} \mathrm{N}, 92^{\circ} 02^{\prime} \mathrm{W}, 29$.VII. 1983 , W. Maddison $\&$ R.S. Anderson; deposited in the Museum of Comparative Zoology, Cambridge, USA; not examined.

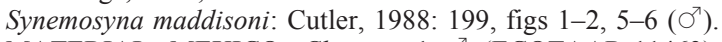
MATERIAL. MEXICO: Chiapas: $1 \sigma^{\top}$ (ECOTAAR-11463), Municipio de Cacahoatán, Ejido Alpujarras $\left(15^{\circ} 4^{\prime} 20.76^{\prime \prime} \mathrm{N}, 92^{\circ} 9^{\prime}\right.$ $\left.57.00^{\prime \prime} \mathrm{W}\right), 922 \mathrm{~m}$ a.s.l., hand collecting in leaf-litter of shadegrown coffee, 20.02.2018, D. Chamé; $1 \sigma^{7}$ (ECOTAAR-2859), Municipio de Tapachula, Finca Irlanda $\left(15^{\circ} 10^{\prime} 23^{\prime \prime} \mathrm{N}, 92^{\circ} 20^{\prime} 10^{\prime \prime} \mathrm{W}\right)$, 830-1100 m a.s.1., 28.03.2003, G. Ibarra; $1 \sigma^{7}$ (ECOTAAR-2456), same locality, 18.10.1988, G. Ibarra; $1 \sigma^{7}$ (ECOTAAR-2733), same locality, 8.08.1999, J.A. García; 1 Ơ, 1 † (ECOTAAR-2512, 2506), same locality, 9.01.1990, J.A. García; 1 ○े, 1 + (ECOTAAR-2497, 2503), same locality, 7.12.1989, J.A. García; 1 ㅇ (ECOTAAR2769), same locality, 7.09.1999, J.A. García.

DIAGNOSIS. The epigyne of $S$. maddisoni resembles those of S. americana and S. ubicki Cutler, 1988 in having an anterior flap, but $S$. maddisoni has a U-shaped flap (Figs 9,11 ) while in $S$. americana it is wide and short (cf. fig. 53 

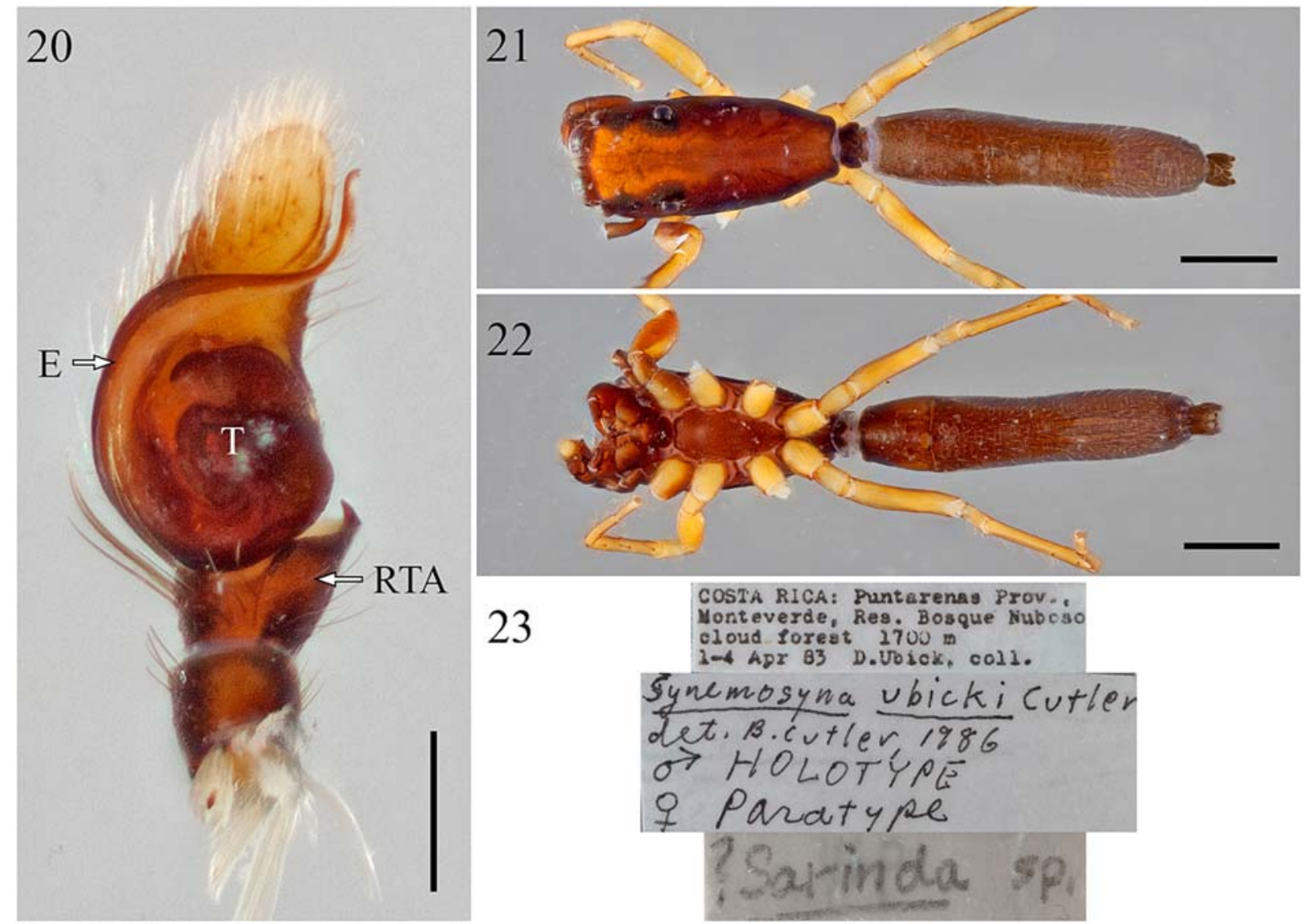

Figs 20-23. Synemosyna ubicki Cutler, 1988: 20 - left male palp, ventral view; 21 - male habitus, dorsal view; 22 - ditto, ventral view; 23 - holotype data labels. CAS TYPE CATALOG: 16496 by the California Academy of Sciences used under CC BY-NC-SA 4.0. Scale bars: $0.25 \mathrm{~mm}(20), 1 \mathrm{~mm}(21-22)$. Abbreviations as explained in 'Material and Methods'.

Рис. 20-23. Synemosyna ubicki Cutler, 1988: 20 - левая пальпа самца, вид снизу; 21 - габитус самца, вид сверху; 22 — тоже, вид снизу; 23 - этикетки голотипа. CAS TYPE CATALOG: 16496 лицензия Калифорнийской академии наук CC BY-NC-SA 4.0. Масштаб: 0,25 мм (20), 1 мм (21-22). Сокращения как объяснено в 'Материалах и Методах’.

in Galiano [1966]) and in S. ubicki slender and long (cf. fig. 9 in Cutler [1988]). In the shape of RTA, the males of $S$. maddisoni resemble those of $S$. ubicki, but the former has RTA extended ventrally (Figs 8, 14-15, 19) and the embolus is shorter than that in S. ubicki (vs. the embolus longer, almost reaching the cymbial tip in $S$. ubicki, cf. Fig. 20 and figs 7-8 in Cutler [1988]).

DESCRIPTION. General appearance as described in Cutler [1985, 1988]. MaLe habitus as in Figs 1-7 (ECOTAAR-11463). Colouration. Carapace with its anterior part yellowish, with black around eyes; posterior part brownish, with subtriangular dark brown spots on margins (Figs 1, 3). Abdomen with three transverse brown stripes that are separated by two pale yellow stripes, followed by two brown chevrons (Figs 2, 4). Legs pale yellow, with brown femora, except leg II. Tibia I and basal half of metatarsus I with lateral brown stripes. Tibia IV brown and metatarsus IV with retrolateral brown stripe. Lateral patches of white scales at carapace median depression and abdominal constriction (Figs 3-4). The dorsal scutum covers roughly $80 \%$ of abdomen (Figs 2,4), post-epigastric scutum covers less than a half of abdominal length (Fig. 6). Chelicerae with four retromarginal denticles and one tooth and one promarginal denticle. Embolus thick and long, encircling a half of bulb (begins at 6 o'clock, ending at 12 o'clock), with a well-devel- oped pars pendula extending beyond the truncus (Figs 8, 13-17, 19) and a spine-like, apical sclerite (Figs 16-17). Subtegulum crescent-shaped (Fig 14). RTA large, extending ventrally, with a retrolateral notch (Figs 8, 14-15, 19). Total length 4.09; carapace 1.81 long, 0.81 wide, 0.65 high at PLE; abdomen 2.28 long, 0.75 wide. Ocular quadrangle length 0.71 , first row width 0.63 , second row width 0.76 , third row width 0.69 , fourth row width 0.78 . Distances AME-ALE 0.06, ALE-PME 0.15, PME-PLE 0.15. Diameter of AME 0.31, ALE 0.13, PME 0.05, PLE 0.12. Cheliceral length 0.35 , clypeal height 0.10 . Length of leg segments: I $2.24(0.71,0.29,0.58,0.38,0.28)$, II $1.95(0.59,0.22,0.51$, $0.36,0.27)$, III $2.35(0.74,0.23,0.60,0.51,0.27)$, IV 3.16 $(0.94,0.28,0.90,0.73,0.31)$. Spination: tibiae I-II v2-2-2; III-IV v0-1-1; metatarsi I-II v2-0-2; III-IV v1-2-2.

Female (ECOTAAR-2506). Colouration faded due to preservation. Dorsal scutum covers only a third of abdominal length and without a post-epigastric scutum. Epigyne with transversal, oval-shaped atrium (Figs 9, 11), the anterior border developed as an overhanging, tongue-shaped flap (Figs 9, 11: AF), rounded spermathecae almost touch each other (Figs 10, 12), copulation duct long and slender, fertilization ducts arise anteriorly at spermathecae (Fig 12). Total length 5.02; carapace 2.1 long, 0.86 wide, 0.64 high at PLE; abdomen 2.92 long, 0.78 wide. Ocular quadrangle length 


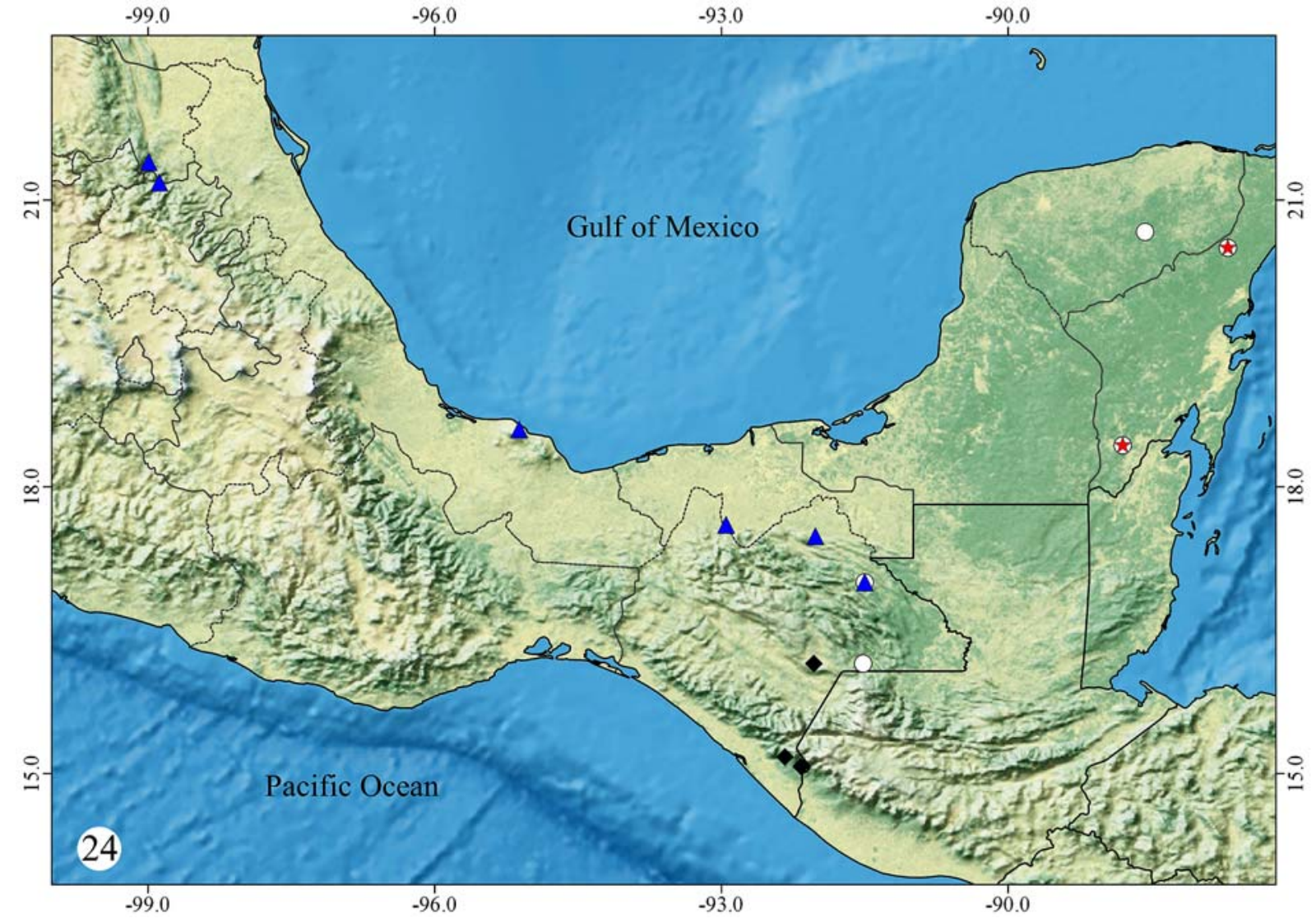

Fig. 24. Collecting localities of Synemosyna and Sympolymnia species (Salticidae) in Mexico: blue triangle - Synemosyna decipiens; white circle - S. americana; black diamond - S. maddisoni; red star - Sympolymnia edwardsi.

Рис. 24. Точки сборов видов Synemosyna и Sympolymnia (Salticidae) в Мексике: голубой треугольник - Synemosyna decipiens; белый кружок - S. americana; черный ромб - S. maddisoni; красная звезда — Sympolymnia edwardsi.

0.77 , first row width 0.69 , second row width 0.83 , third row width 0.76 , fourth row width 0.85 . Distances AME-ALE 0.06, ALE-PME 0.15, PME-PLE 0.13. Diameter of AME 0.26 , ALE 0.14, PME 0.05, PLE 0.15. Cheliceral length 0.19 , clypeal height 0.06 . Length of leg segments: I 2.23 $(0.72,0.26,0.58,0.40,0.27)$, II $2.11(0.68,0.23,0.53,0.40$, $0.27)$, III $2.58(0.81,0.26,0.69,0.54,0.28)$, IV $3.45(1.09$, $0.33,0.97,0.77,0.29)$. Spination of forelegs as in the male, hindlegs spineless.

VARIATION. Males ( $\mathrm{n}=6$ ) usually with one spine missing at retrolateral side of tibiae or metatarsi III-IV; total length $4.46 \pm 0.36$; carapace $2.04 \pm 0.15$ long, $0.91 \pm 0.09$ wide; abdomen $2.42 \pm 0.22$ long, $0.72 \pm 0.09$ wide. Females $(n=3)$ hindlegs without spines; total length $4.92 \pm 0.11$; carapace $2.06 \pm 0.06$ long, $0.85 \pm 0.01$ wide; abdomen $2.85 \pm 0.05$ long, $0.78 \pm 0.03$ wide.

DISTRIBUTION. Mexico (Fig. 24): Chiapas [Cutler, 1988; present data], and Guatemala: Jalapa [Cutler, 1988], Izabal [GBIF, 2019] and Petén [GBIF, 2019].

HABITAT. This species occurs in shade-grown coffee plantations (830-1100 m a.s.1.), disturbed oak-pine (1066 m a.s.1.) and oak forests [Cutler, 1985, 1988; present data].

REMARKS. Cutler [1988] did not mention that $S$. maddisoni has a pars pendula, although he illustrated a darker outer margin of the embolus. An embolus with pars pendula is a character shared by $S$. maddisoni with $S$. ankeli Cutler et Müller, 1991 (fig. 5 in Cutler \& Müller [1991]) and $S$. ubicki (inferred with photos of the holotype, Fig. 20 [California Academy of Sciences used under CC BY-NC-SA 4.0, catalog: 16496, Record Id: e5570efd-6c1b-4f94-b9ea59296af7af5d]). Even though a post-epigastric scutum and spines on hindlegs were not mentioned for $S$. ubicki, the holotype has both characters (Fig. 22), as does the male of $S$. maddisoni. Most records of Synemosyna species in México originated from the southern region (Fig. 24), although records from online databases (GBIF, Portal de Datos Abiertos UNAM) suggest that the genus is also distributed in the west of the country. Richman \& Cutler [2008] stated that $S$. americana is distributed in Tabasco and $S$. decipiens in Campeche, but we failed to find these records (with references) in the reviewed papers.

Acknowledgements. We are grateful to G. Suárez and E.R. Chamé (ECOSUR) for helping us with image acquisition, R. Bautista and L. Solís (ECOSUR) for providing access to the microscopy equipment, and D.V. Logunov (Manchester Museum, UK) for the editorial help.

\section{Compliance with ethical standards}

Conflict of Interest: The authors declare that they have no conflict of interest.

Ethical approval: No ethical issues were raised during our research. 


\section{References}

Álvarez-Padilla F., Hormiga G. 2008. A protocol for digesting internal soft tissues and mounting spiders for scanning electron microscopy // Journal of Arachnology. Vol.35. No.3. P.538542. https://doi.org/10.1636/Sh06-55.1

Comstock J.H. 1910. The palpi of male spiders // Annals of the Entomological Society of America Vol.3. No.3. P.161-185. https://doi.org/10.1093/aesa/3.3.161

Cutler B. 1985. Taxonomic notes on Neotropical species in the genus Synemosyna (Araneae: Salticidae) // Studies on Neotropical Fauna and Environment. Vol.20. No.2. P.83-91. https:// doi.org/10.1080/01650528509360674

Cutler B. 1988. Middle American Synemosyna (Araneae: Salticidae), a key and description of a new species // Studies on Neotropical Fauna and Environment. Vol.23. No.4. P.197202. https://doi.org/10.1080/01650528809360763

Cutler B., Müller H.-G. 1991. The spider genus Synemosyna in northern Colombia (Araneae: Salticidae) // Studies on Neotropical Fauna and Environment. Vol.26. No.3. P.171-177. https://doi.org/10.1080/01650529109360850

Galiano M.E. 1963. Las especies americanas de arañas de la familia Salticidae descriptas por Eugène Simon: Redescripciones basadas en los ejemplares típicos // Physis, Revista de la Sociedad Argentina de Ciencias Naturales. Vol.23. P.273-470.

Galiano M.E. 1966. Salticidae (Araneae) formiciformes V. Revisión del género Synemosyna Hentz, 1846 // Revista del Museo Argentino de Ciencias Naturales Bernardino Rivadavia (Ent.) Vol.1. P.339-380.
GBIF 2019. Synemosyna maddisoni Cutler, 1985: GBIF Backbone Taxonomy, online at: https://www.gbif.org/, accessed on 29.03.2020. https://doi.org/10.15468/39omei

Maddison W.P. 2015. A phylogenetic classification of jumping spiders (Araneae: Salticidae) // Journal of Arachnology. Vol.43. No.3. P.231-292. https://doi.org/10.1636/arac-43-03-231-292

Oliveira P.S. 1988. Ant-mimicry in some Brazilian salticid and clubionid spiders (Araneae: Salticidae, Clubionidae) // Biological Journal of the Linnean Society. Vol.33. No.1. P.1-15. https://doi.org/10.1111/j.1095-8312.1988.tb00443.x

Perger R., Rubio G.D. 2020. Sympolymnia, a new genus of Neotropical ant-like spider, with description of two new species and indirect evidence for transformational mimicry (Araneae, Salticidae, Simonellini) // Zoosystematics and Evolution. Vol.96. No.2. P.781-795.

Petrunkevitch A. 1925. Arachnida from Panama // Transactions of the Connecticut Academy of Arts and Sciences. Vol.27. P.51248.

Ramírez M.J. 2014. The morphology and phylogeny of Dionychan spiders (Araneae: Araneomorphae) // Bulletin of the American Museum of Natural History. No.390. P.1-390. https://doi.org/ $10.1206 / 821.1$

Reiskind J. 1977. Ant-mimicry in Panamanian clubionid and salticid spiders (Araneae: Clubionidae, Salticidae) // Biotropica. Vol.9. No.1. P.1-8

Richman D.B., Cutler B. 2008. A list of the jumping spiders of Mexico // Peckhamia. Vol.62. No.1. P.63-88.

WSC 2020. World Spider Catalog. Version 21.0. Natural History Museum Bern (accessed on 15.03.2020); online at: http://wsc. nmbe.ch

Responsible editor D.V. Logunov 